\title{
Effects of Hexachlorocyclohexane (HCH- $\gamma$-Isomer, Lindane) Intoxication on the Proliferation and Apoptosis in Rat Testes
}

\author{
Hayati Yuksel, Erkan Karadas, Hikmet Keles, Hasan Huseyin Demirel \\ Department of Pathology, Faculty of Veterinary Medicine, Afyon Kocatepe University, Afyonkarahisar, Turkey \\ Received September 1, 2008 \\ Accepted May 18, 2009
}

\begin{abstract}
In this study, experimentally lindane-induced histopathological changes and proliferation and/or apoptosis in germ cells in the rat testes were investigated. A total of 40 healthy fertile 3 -month-old male rats were used. Animals were divided into 4 groups, each containing 10 rats. Group 1 (control) was given only pure olive oil, Groups 2, 3 and 4 were administered lindane at 10,20 and $40 \mathrm{mg} / \mathrm{kg} / \mathrm{bw}$, respectively, by gastric gavage for 30 days. Microscopically, degenerative changes were observed in the lindane-treated groups. For proliferative activity PCNA immunolabelling and for germ cells apoptosis TUNEL methods were performed. Although a strong PCNA positivity in the control group was observed, a gradual decrease was noted in the lindane-treated groups especially at higher doses. Significant increases of apoptosis were seen in the lindane-treated groups compared to the control group. A decrease in testosterone concentrations was observed in lindane-treated groups compared to the control group. The study indicates that high-dose lindane intoxication contributes to the suppression of spermatogenesis through a reduction of germ cell proliferation and an increase of germ cell death in rat testes.
\end{abstract}

Lindane, spermatogenesis, germ cells, apoptosis, PCNA, testosteron

Lindane, the gamma-isomer of hexachlorocyclohexane, is an organochlorine pesticide widely used as a broad-spectrum insecticide to control agriculture pests and ectoparasites in both humans and animals (Dalsenter et al. 1996; Samanta and Chainy 2002; Choudhary and Joshi 2003). It causes damage to the male reproduction tract either acting directly on the testes or indirectly through endocrine regulation of the testes (Dalsenter et al. 1996; Dalsenter et al. 1997).

Several studies have demonstrated that lindane disrupts the reproductive function in male and female animals (Shivanandappa and Krishnakumari 1983; Srinivasan et al. 1988; Dalsenter et al. 1996). In male rats, chronic lindane exposures markedly reduce sperm counts, sperm motility and impair spermatogenesis. In addition, serum testosterone concentrations decrease in lindane intoxication (Chowdhury and Gautam 1994; Prasad et al. 1995; Dalsenter et al. 1996; Kuriyama 2005).

According to the WHO, $\mathrm{LD}_{50 \mathrm{~S}}$ for lindane in male rats ranges between $88-190 \mathrm{mg} / \mathrm{kg} / \mathrm{bw} / \mathrm{day}$. Lindane had a toxic effect on the reproductive system at the dose of $5 \mathrm{mg} / \mathrm{kg} / \mathrm{bw} /$ day and higher doses in rodents (Dalsenter et al. 1997; FAO/WHO 2002). In previous studies, lindane was used at the doses of $1-30 \mathrm{mg} / \mathrm{kg} / \mathrm{bw}$ in 30-90-day-old male rats and degenerative changes were reported (Chowdhury et al. 1987; Srinivasan et al. 1988; Dalsenter et al. 1996; Dalsenter et al. 1997; Walsh and Stocco 2000; Samanta and Chainy 2002).

There have been many investigations on proliferation and apoptosis of testicular germ cell in rats using chemical agents (Cai et al. 1997; Foster et al. 1999; Hu et al. 2003; Kuriyama et al. 2005; Koh and Kim 2006) but, to our knowledge, there is no published report on the effects of lindane on this matter. This study was therefore aimed to investigate the effects of 10,20 and $40 \mathrm{mg} / \mathrm{kg} / \mathrm{bw} /$ day on proliferation and apoptosis in testicular germ cells of male rats considering the toxic and lethal doses of lindane.

Address for correspondence:

Hayati Yuksel

Department of Pathology, Faculty of Veterinary Medicine

Afyon Kocatepe University, 03200, Afyonkarahisar,

Turkey
Phone: +902722228 13 12/153Fax:

Fax: +90 2722281349

E-mail: hyukse169@aku.edu.tr, hyuksel69@hotmail.com

http://www.vfu.cz/acta-vet/actavet.htm 


\section{Materials and Methods}

All experiments were performed on 3-month-old Sprague Dawley rats (280-300 g) obtained from the University of Suleyman Demirel, Isparta, Turkey. Throughout the study, the animals were housed in a climate-controlled room $\left(24^{\circ} \mathrm{C}\right)$ with a regular light cycle $(12 \mathrm{~h}$ light: $12 \mathrm{~h}$ dark). They had free access to standard rodent chow and tap water ad libitum. Lindane (HCH-gamma-isomer, Aldrich, CAS Number 58-89-9) was purchased from Sigma-Aldrich Co. Ltd-Gillingham-Dorset-SP84XT-UK. Experimental animals were divided into 4 groups of 10 rats each: Group 1 (Control) - $1 \mathrm{ml} /$ day pure olive oil, Group 2-10 mg/kg/bw, Group 3-20 mg/kg/bw, and Group $4-40 \mathrm{mg} / \mathrm{kg} / \mathrm{bw}$ lindane. Lindane was freshly dissolved in olive oil and given at $1 \mathrm{ml}$ daily by gastric gavage for 30 days. The clinical findings were recorded during the experimental period.

A day after the final administration, blood samples were collected from all animals by cardiac puncture under general anaesthesia and serum samples were separated by centrifugation $(1500 \mathrm{~g}$ for $10 \mathrm{~min})$ and stored at $-20^{\circ} \mathrm{C}$ until analyzed. Testosterone concentrations were determined by Chemiluminescence Immuno-Assay. After blood collection, the rats were sacrificed and necropsy was performed. Each testis was removed, weighed and fixed in Bouin's solution. Tissues were embedded in paraffin, sectioned at $5 \mu \mathrm{m}$ thickness, and stained with haematoxylin and eosin (HE).

PCNA immunostaining

Paraffin sections $(5 \mu \mathrm{m})$ were mounted on silanized slides for immunohistochemistry. PCNA immunostaining was carried out using the Avidin-Biotin-Complex Peroxidase (ABC-P) method. After deparaffinization and rehydration, endogenous peroxides and non-specific immunoglobulins were blocked with the super block system (ScyTEK/Logan, Utah, USA) for $10 \mathrm{~min}$. Monoclonal Mouse Anti-Rat Proliferating Cell Nuclear Antigen (PCNA, Clone PC10; Dako Carpinteria, CA, USA) was applied for $1 \mathrm{~h}$; then UltraTek Anti-Polyvalent Biotinylated Antibody (ScyTEK/Logan, Utah, USA) was applied for $10 \mathrm{~min}$ and UltraTek HRP for $10 \mathrm{~min}$. Colour was developed by incubation with 3-amino-9-ethylcarbazole (AEC, Dako, Carpinteria, CA, USA) for 5 min. Finally, the sections were counterstained with Mayer's haematoxylin for $3 \mathrm{~min}$ and cover slips were applied with the aqueous mounting medium. Negative controls were performed using Phosphate Buffered Saline (PBS, pH 7.4) in the place of the primary antibody. A total of 1,000 germ cells in different seminiferous tubules of consecutive fields were counted at higher magnification on each slide and PCNA positive cells were statistically evaluated.

Detection of apoptotic cells

Apoptotic seminiferous cells were detected by terminal deoxynucleotidyl transferase-mediated dUTP nick end-labelling (TUNEL) stain using a commercial ready-to-use kit (In Situ Cell Death Detection Kit, POD, Roche, Mannheim, Germany). The procedure was carried out according to the manufacturer's instructions. Paraffin sections $(5 \mu \mathrm{m})$ were mounted on silanized slides for the TUNEL method. After deparaffinization and rehydration, sections were digested with proteinase $\mathrm{K}(20 \mu \mathrm{g} / \mathrm{ml}, 30 \mathrm{~min})$ and quenched with $3 \%$ hydrogen peroxide in methanole. Sections were incubated in a humidified chamber in $200 \mu \mathrm{l}$ of TUNEL (TdT and label solution) at $37^{\circ} \mathrm{C}$ for $60 \mathrm{~min}$ and with POD converter at $37^{\circ} \mathrm{C}$ for $30 \mathrm{~min}$. The sections were then treated with AEC for 5 min, washed with PBS and counterstained with Mayer's haematoxylin. Negative control slides omitting the label solution were also included. The percentage of apoptotic germ cells was determined by counting a total of 1,000 germ cells from apoptotic tubule cross-sections of each specimen (Yin et al. 1998). To quantify the incidence of apoptosis, the seminiferous tubules containing three or more TUNEL positivity were calculated. Apoptotic positive cells were statistically evaluated.

All the experimental protocols approved by the Care and Use of Animal Committee of Afyon Kocatepe University were performed in compliance with the National Institute of Health guidelines for the care and use of animals.

Statistical analysis

Statistical differences were determined by using ANOVA. Post-hoc comparisons between the means of experimental groups were determined using Duncan protected least-significant-difference test. Differences with $p<0.05$ were considered significant.

\section{Results}

After the second week, the rats in groups 2, 3 and 4 showed clinical signs of hunch backing and dullness of the coat. During the experiment, 2 rats (1 rat from Group 3 and 1 rat from Group 4) died in the third week. At the end of the experiment, no significant macroscopical findings in the testes were observed in any experimental group.

Microscopically, no significant changes were observed in the testes of animals in Group 1. In the lindane-treated groups, shrinkage in seminiferous tubules, sloughing of germinal cells towards the lumen, sperm loss, and vacuolization in sustentacular (Sertoli) cells and spermatogonia in the seminiferous tubules were observed. Furthermore, the interstitial 
space was increased and filled with oedematous fluid and degeneration and reduced nuclear size in the interstitial (Leydig) cells were recorded in these groups.

\section{Apoptosis Index}

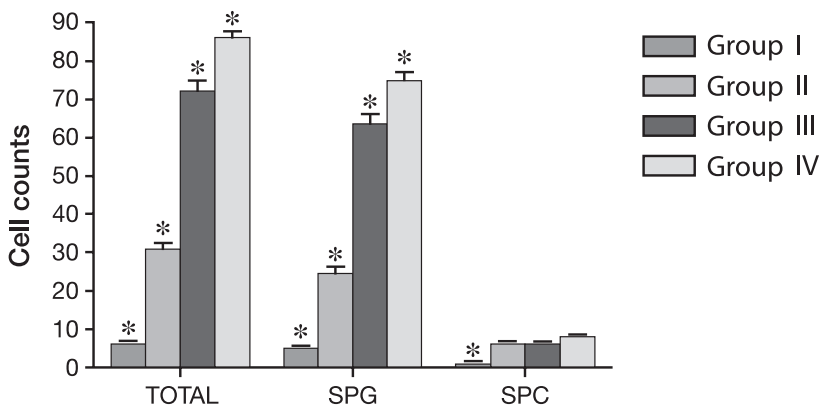

Fig. 1. Quantification of germ cell proliferation in the control (Group 1) and lindane-treated groups (Groups 2-4). SPG: spermatogonia; SPC: spermatocyte; TOTAL: SPG + SPC

*Significant difference $(p<0.05)$

This study showed that lindane administration markedly decreased the PCNA expression in germ cells (Fig. 1). Despite many positive signals in the nuclei of spermatogonia and spermatocytes in the control and the lindane-treated groups, the sustentacular cells, spermatids and interstitial cells remained unstained. In spite of a strong PCNA-positivity together with spermatogonia and spermatocytes (Plate IV, Fig. 3A), gradual decreases were observed in the lindane-treated groups (Fig. 3B, C and D). Comparing the PCNA-positive spermatogonia and spermatocytes, a significant difference was found between the control and lindane-treated groups and in addition, between the lindane-treated groups. Significant results were obtained between control and all lindane-treated animals when only PCNApositive spermatocytes were taken into account, but these differences were not significant between lindane-treated groups.

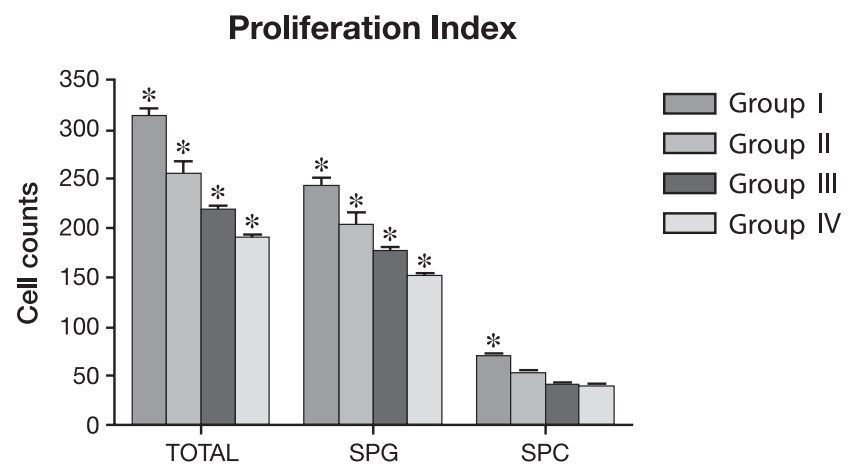

Fig. 2. Quantification of germ cell apoptosis in the control (Group 1) and lindane-treated groups (Groups 2-4). SPG: spermatogonia; SPC: spermatocyte; TOTAL: SPG + SPC

*Significant difference $(p<0.05)$

A significant increase in apoptotic spermatogonia and spermatocytes were determined in groups 2, 3 and 4 (Fig. 2) compared to the control group. In the control group a normal structure of seminiferous epithelium with only slight apoptotic signs was seen (Plate IV, 
Fig. 4A). However, the number and density of TUNEL positive cells in the lindane-treated groups was higher in spermatogonia, lower in spermatocytes and to the least degree in spermatids (Fig. 4B, C and D).

Comparing the apoptotic spermatogonia and spermatocytes between the control and lindane-treated groups, a significant increase was found. Whereas significant differences were observed in the number of apoptotic spermatocytes between the control and the lindane-treated groups, no significant differences were determined between the experimental groups. No apoptotic spermatids were observed in groups 1 and 2 . In groups 3 and 4 apoptotic spermatids were not taken into consideration because the number of these cells was found to be less than three.

In the biochemical analysis, serum testosterone concentrations were found to be $2.52 \mathrm{ng} / \mathrm{ml}, 1.01 \mathrm{ng} / \mathrm{ml}, 0.27 \mathrm{ng} / \mathrm{ml}$ and $0.24 \mathrm{ng} / \mathrm{ml}$ for groups $1,2,3$ and 4 , respectively. A gradual decrease in testosterone concentration was observed in the lindane-treated groups compared to the control group.

\section{Discussion}

Organic chlorine compounds may cause testicular atrophy, shrinking of the seminiferous tubules, desquamation of germinal epithelium in to lumen, degeneration of sustentacular cells, interstitial cells, spermatogonia and spermatocytes and also formation of giant cells in the tubular lumen, decrease of spermatogenesis, abnormal sperm production and fertilization disorders in male rats (Shivanandappa and Krishnakumari 1983; Srinivasan et al. 1988; Dalsenter et al. 1996; Nonclerq et al. 1996; Chitra et al. 1999; Raizada et al. 2001) and mice (Yin et al. 1998; Samanta and Chainy 2002; Hu et al. 2003). Similar histopathological changes were found in groups 2, 3 and 4 of our study, while no major pathological changes were observed in group 1.

Studies show that organic chlorine compounds have an inhibitory effect on the testicular hormones in male rats (Lindenau et al. 1994; Prasad et al. 1995; Walsh and Stocco 2000). Testosterone is the principal hormone ensuring normal spermatogenesis and inhibition of germ cell apoptosis (Dohle et al. 2003). In the present study, a gradual decrease in serum testosterone level was determined in the lindane-treated groups and this hormonal disturbance was associated with the interstitial cell degeneration.

PCNA is known as a 36-kDa dimensional nuclear protein, releases in the S-phase of late cell cycle G1 and in conjunction with the DNA during the replication. Thus, PCNA is considered a useful marker of cell proliferation. In the testes, PCNA is expressed in spermatogonia and early phase primary spermatocytes in all stages of seminiferous tubules. In the present study, PCNA positivity was determined in spermatogonia and spermatocytes in all groups. The decrease of PCNA positivity with the increasing lindane doses in comparison to the control group may indicate that the lindane had an inhibiting effect on the proliferative activity in the seminiferous tubules. This situation can be interpreted in the light of existing literature (Koh and Kim 2006). Lindane might have repressed the proliferation of spermatogonia and spermatogenesis in rat testes in our study, too.

Apoptotic changes were reported in spermatogonia, spermatocytes and spermatids of rat testes after using chemotherapeutic agents (Cai et al. 1997) and some testicular toxins (Foster et al. 1999; Choudhary and Joshi 2003; Hu et al. 2003; Kuriyama et al. 2005). Apoptosis is a normal process for mammal germ cells during spermatogenesis. In adult rats, these losses are mostly observed during spermatogonial development and to a lesser extend during maturation of spermatocytes and spermatids (Hikim et al. 2003). Apoptotic appearances of spermatids are rare because apoptotic cells are phagocytosed by sustentacular cells (Blanco-Rodriguez and Martinez-Garcia 1999; Cai et al. 1997; Hikim and Swerdloff 1999). 
In this study, it was important that the incidence of apoptosis in spermatogonia and spermatocytes increased in treated groups in parallel to the amount of administered lindane. Apoptosis was detected mostly in the spermatogonia within the seminiferous tubules, and at a lower ratio in the spermatocytes. However, apoptosis in spermatids was considered non-significant. The low incidence of apoptopic spermatids in the lindane-treated groups can be explained by these cells in the seminiferous tubules being phagocytosed by sustentacular cells, which has also been reported by other researchers (Cai et al. 1997; Blanco-Rodriguez and Martinez-Garcia 1999; Hikim and Swerdloff 1999; Hikim et al. 2003). In the previous study, we have investigated the effect of lindane on antioxidant defense systems, lipid peroxidation and NOx of blood and liver, brain, kidney tissues of rats, by histopathological examination and biochemical analysis. It was concluded that lindane induced oxidative stress in blood and tissues by decreasing the activities of antioxidant enzymes and generation of free radicals in rats (Fidan et al. 2008).

This study indicates that high-dose lindane intoxication contributes to the suppression of spermatogenesis through a reduction of germ cell proliferation and an increase of germ cell death in rat testes.

\section{Vliv intoxikace hexachlorcyklohexanem (HCH- $\gamma$-Izomer, Lindan) na proliferaci a apoptózu buněk varlete u potkana}

V práci byly zkoumány histopatologické změny, proliferace a apoptóza potkaních zárodečných buněk varlete způsobené podáváním lindanu. Do experimentu bylo zahrnuto celkem 40 zdravých fertilních potkaních samců ve věku 3 měsíce. Zvířata byla rozdělena do 4 skupin po 10 jedincích. Potkanům ve skupině 1 (kontrola) byl během pokusu podáván pouze čistý olivový olej. Skupinám 2, 3 a 4 byl žaludeční sondou aplikován lindan v množství 10, 20 a $40 \mathrm{mg} / \mathrm{kg}$ ž. hm. po dobu 30 dní. U zvírat z pokusných skupin se vyskytovaly degenerativní změny zjištěné mikroskopicky. Proliferace buněk byla určována na základě imunohistochemického stanovení proliferačního markeru PCNA a pro sledování apoptózy zárodečných buněk byla použita TUNEL metoda. Ačkoliv byla pozorována silná PCNA pozitivita u potkanů v kontrolní skupině, u pokusných jedinců byl zaznamenán postupný pokles exprese PCNA, zvláště u jedinců ve skupinách, kterým byly podávány vyšší dávky lindanu. Ve skupinách zviŕat, kterým byl podáván lindan, došlo k signifikantnímu nárůstu apoptózy zárodečných buněk varlete a byl zjištěn pokles koncentrace testosteronu.

\section{Acknowledgements}

This study was supported by Afyon Kocatepe University, Turkey, Scientific Research Project Council, Project Number 06 VF 19.

\section{References}

Blanco-Rodríguez J, Martínez-García C 1999: Apoptosis is physiologically restricted to a specialized cytoplasmic compartment in rat spermatids. Biol Reprod 61: 1541-1547

Cai L, Hales BF, Robaire B 1997: Induction of apoptosis in the germ cells of adult male rats after exposure to cyclophosphamide. Biol Reprod 56: 1490-1497

Chitra KC, Sujatha R, Latchoumycandane C, Mathur PP 2001: Effect of lindane on antioxidant enzymes in epididymis and epididymal sperm of adult rats. Asian J Androl 3: 205-208

Choudhary N, Joshi SC 2003: Reproductive toxicity of endosulfan in male albino rats. Bull Environ Contam Toxicol 70: 285-289

Chowdhury AR, Venkatakrisha-Bhatt H, Gautam AK 1987: Testicular changes of rats under lindane treatment Bull Environ Contam Toxicol 38: 154-156

Chowdhury AR, Gautam AK 1994: Steroidogenic impairment after lindane-treatment in male rats. JUOEH 16: 145-152

Dalsenter PR, Faqi AS, Webb J, Merker HJ, Chahoud I 1996: Reproductive toxicity and tissue concentrations of lindane in adult male rats. Hum Exp Toxicol 15: 406-410

Dalsenter PR, Faqi AS, Webb J, Merker HJ, Chahoud I 1997: Reproductive toxicity and toxicokinetics of lindane in the male offspring of rats exposed during lactation. Hum Exp Toxicol 16: 146-153 
Dohle GR, Smit M, Weber RFA 2003: Androgen and male infertility. World J Urol 21: 341-345

FAO/WHO (Food and Agriculture Organization/World Health Organization) 2002: Pesticide residues in food, Lindane, pp 181-186. Report of the joint meeting of the FAO panel of experts on pesticide residues in food and environment and the WHO core assessment group on pesticide residues. Rome, Italy 16-25 September

Fidan AF, Cigerci IH, Sozbilir NB, Kucukkurt I, Yuksel H, Keles H 2008: The effects of the dose-dependent hexachlorocyclohexane (Lindane) on blood and tissue antioxidant defense systems, lipid peroxidation and histopathological changes in rats. J Anim Vet Adv 7: 1480-1488

Foster WG, Desaulniers D, Leingartner K, Wade MG, Poon R Chu I 1999: Reproductive effects of tris (4-chlorophenyl) methanol in the rat. Chemosphere 39: 709-724

Hikim AP, Swerdloff RS 1999: Hormonal and genetic control of germ cell apoptosis in the testis. Rev Reprod 4: $38-47$

Hikim AP, Lue Y, Yamamoto CM, Vera Y, Rodriguez S, Yen PH, Soeng K, Wang C, Swerdloff RS 2003: Key apoptotic pathways for heat-induced programmed germ cell death in the testis. Endocrinology 144: 31673175

Hu JH, Jiang J, Ma YH, Yang N, Zhang MH, Wu M, Fei J, Guo LH 2003: Enhancement of germ cell apoptosis induced by ethanol in transgenic mice overexpressing Fas Ligand. Cell Res 13: 361-367

Koh PO, Kim MO 2006: Ethanol exposure decreases cell proliferation and increases apoptosis in rat testes. J Vet Med Sci 68: 1013-1017

Kuriyama K, Kitamura T, Yokoi R, Hayashi M, Kobayashi K, Kuroda J, Tsujii H 2005: Evaluation of testicular toxicity and sperm morphology in rats treated with methyl methanesulphonate (MMS). J Reprod Dev 51: 657-667

Lindenau A, Fischer B, Seiler P, Beier HM 1994: Effects of persistent chlorinated hydrocarbons on reproductive tissues in female rabbits. Hum Reprod 9: 772-780

Nonclerq D, Reverse D, Toubeau G, Beckers JF, Sulon J, Laurent G, Zanen J, Heuson-Stiennon JA 1996: In situ demonstration of germinal cell apoptosis during diethylstilbestrol-induced testis regression in adult male Syrian hamsters. Biol Reprod 55: 1368-1376

Prasad AK, Pant N, Srivastava SC, Kumar R, Srivastava SP, 1995: Effect of dermal application of hexachlorocyclohexane $(\mathrm{HCH})$ on male reproductive system of rat. Hum Exp Toxicol 14: 484-488

Raizada RB, Srivastava MK, Kaushal RA, Singh RP, Gupta KP 2001: Subchronic oral toxicity of a combination of insecticide (HCH) and herbicide (ISP) in male rats. J Appl Toxicol 21: 75-79

Samanta L, Chainy GB 2002: Response of testicular antioxidant enzymes to hexachlorocyclohexane is species specific. Asian J Androl 4: 191-194

Saradha B, Vaithinathan S, Mathur PP 2008: Single exposure to low dose of lindane causes transient decrease in testicular steroidogenesis in adult male wistar rats. Toxicology 244: 190-197

Shivanandappa T, Krishnakumari MK 1983: Hexachlorocyclohexane-induced testicular dysfunction in rats. Acta Pharmacol Toxicol (Copenh) 52: 12-17

Srinivasan K, Ramesh HP, Radhakrishnamurty R 1988: Changes induced by hexachlorocyclohexane isomers in rat liver and testis. Bull Environ Contam Toxicol 414: 531-539

Walsh LP, Stocco DM 2000: Effects of lindane on steroidogenesis and steroidogenic acute regulatory protein expression. Biol Reprod 63: 1024-1033

Yin Y, Dewolf WC, Morgentaler A 1998: Experimental cryptorchidism induces testicular germ cell apoptosis by p53-dependent and -independent pathways in mice. Biol Reprod 58: 492-496 
Plate IV

Yuksel H. et al.: Effects of ... pp. 615-620

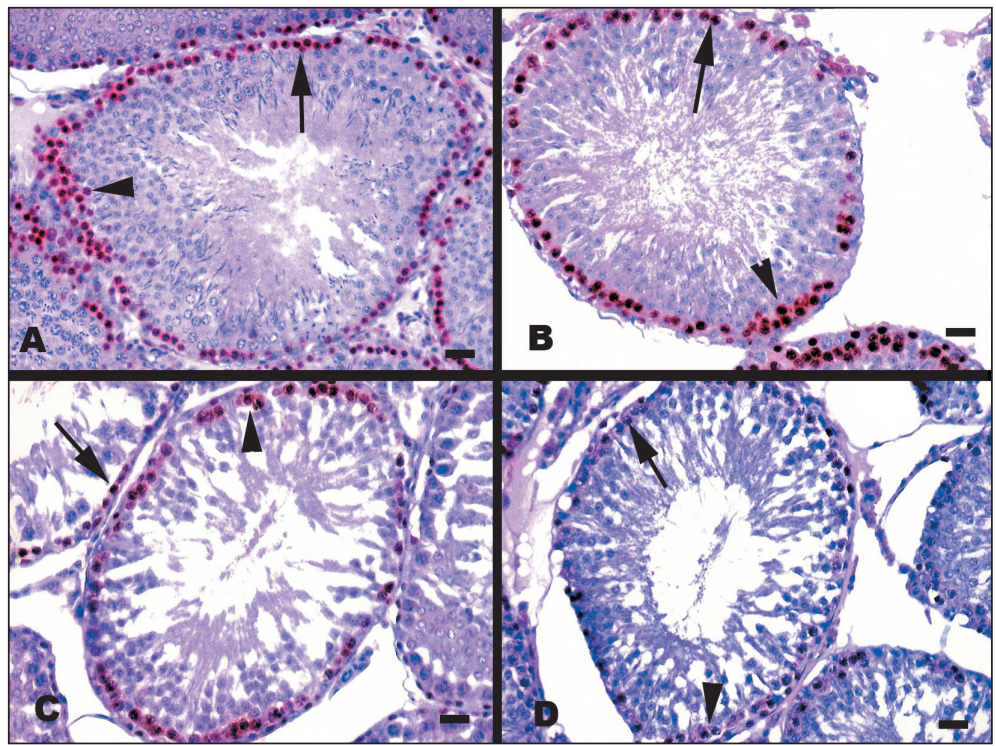

Fig. 3. Expression of PCNA in the testicular tissue of control (A) and lindane-treated groups (B, C and D). Positively stained cells were significantly decreased in the lindane-treated groups (from the strongest to the weakest; B: Group 2, C: Group 3 and D: Group 4) positive staining in spermatogonia (arrows) and in spermatocytes (arrowheads). ABC-P method with Mayer's haematoxylin counterstain. Bar: $20 \mu \mathrm{m}$ in A, B, C and D

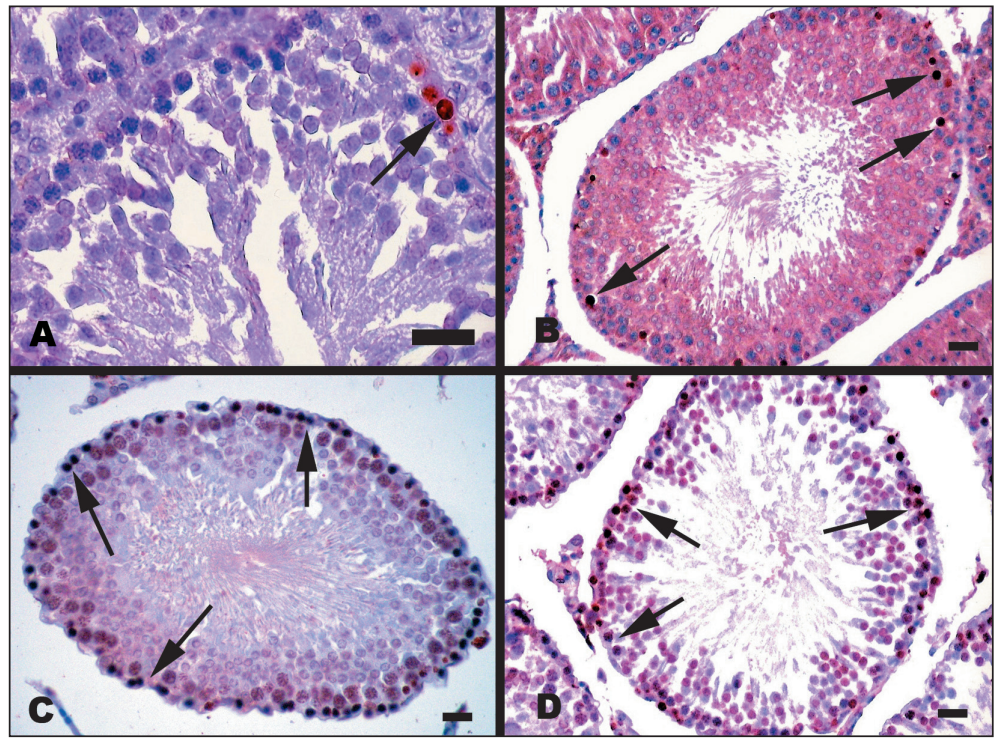

Fig. 4. Representative photomicrographs of TUNEL stained testes in control and lindane-treated groups. A - control group shows only an occasional apoptotic germ cell (arrow) B - lindanetreated group 2, note an increase in the number of TUNEL positive germ cells (arrows) C, D. Lindane-treated groups 3 and 4, testicular tissue shows a marked increase in the number of TUNEL positive germ cells (arrows). Mayer's haematoxylin counterstain; bar: $40 \mu \mathrm{m}$ in A and $20 \mu \mathrm{m}$ in $\mathrm{B}, \mathrm{C}$ and $\mathrm{D}$ 